(in company with Mr. G. Bonsor, Dr. Thelwell, and Mr. Mallett) we found in the blown sand above the cliff near Constantine Island many traces of hearths, at different levels, down to a depth of 8 feet from the highest point of the midden. There were charcoal, burnt bones, and shells of Patella vulgata, Cordium edule, and Mytilus edulis (some showing traces of the action of fire on them). The fact of the differing levels of these hearths seems to show a prolonged occupation of the Trevose peninsula by Neolithic man or his descendants in the Bronze or early Iron ages. There is an extensive circular midden round Constantine Church (ruins), there are others covered with blown sand that can be identified by the shells and bones turned out by rabbits in making their burrows. Also an extensive midden occurred at the Harlyn Bay late Keltic burialground. I say occurred, because it has been levelled and planted with trees. From that kitchen-midden were obtained teeth of Bos taurus, Sus scrofa, and shells of Mytilus, Patella, Helcion, etc., and quantities of broken Purpura lapillus, which $\mathrm{Ir}$. Santer Kennard, F.G.S., considered were thus broken to extract colour for dyeing. I cannot verify the reference, as I do not keep the Illustrated London News, but, as far as I remember, Mr. George Bonsor, whose discoveries near Carmona have given him a European reputation, found somewhat similar conditions as to kitchen-middens and cooking-sites near St. Mary's in the Scilly Isles, but, so far as I know, his paper on this work has not set appeared.

i. Ashivgton Bullen.

Wokisg.

Febriary 5 th, 1908.

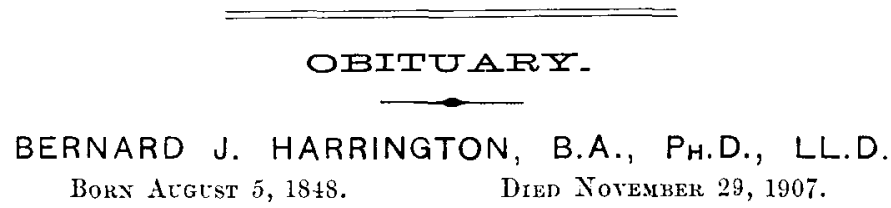

We regret to record the death of Dr. B. J. Harrington, who was formerly chemist and mineralogist to the Geological Survey of Canada, and subsequently Professor of Mining and also of Chemistry in McGill University, Montreal. Born in the province of Quebec he was educated at McGill University, and afterwards graduated Ph.D. at Yale. In 1872 he succeeded Dr. T. Sterry Hunt as chemist and mineralogist to the Canadian Geological Survey under Selwyn. To the publications of that Survey he contributed reports and analyses of coals, iron-ores, and sundry minerals. He also prepared a catalogue of the Canadian minerals, rocks, and fossils exhibited in the Paris Exhibition of 1878 . He described the new mineral Dawsonite (1874), wrote on the microscopic structure of dykes cutting the Laurentian rocks (1877), and on the minerals of some of the apatite-bearing veins of Ottawa County (1879). In later years he contributed papers on mineralogical subjects to the Transactions of the Royal Society of Canada, the American Journal of Science, and other journals. He had been President of the Chemical and Physical Section of the Royal Society of Canada, and he was appointed a Vice-President of 
the Chemical Section of the British Association at the meeting held in Toronto.

Dr. Harrington was perhaps most widely known in this country as author of the interesting "Life of Sir William E. Logan," which was published in 1883 .

\section{ROBERT LAW, F.G.S.}

Bory June 21, 1810.

Died December 29, 1907 .

The late Mr. Robert Law, whose death took place at the close of last year, was in many respects a remarkable man. Born at Walsden in Lancashire, on the borders of Yorkshire, he commenced the business of life as a weaver, but was attracted in his leisure hours to the local Working Men's Club and Institute, where his interest was aroused in the Natural History and Archæology of his neighbourhood. Although at the time he was regarded as " a very rough unpolished diamond," set, after passing through a course of instruction in what may be called elementary subjects, he became passionately devoted to the study of geology, spending what little spare money he had on books and fossils, and his spare time in reading or in tramping the district for miles around. In this way he became so proficient in geological science that he was recognised as its leading exponent in the country round Walsden. $\mathrm{He}$ soon widened his sphere of operations, his wanderings taking him to the Mountain Limestone districts of Castleton, Derbyshire, to Clitheroe in Lancashire, and to the Lias of the Yorkshire coast:

About 30 years ago he commenced his first class in geology at Todmorden, under the auspices of the local Science and Art Committee, and in the same year he had a similar class at the Institute at Walsden. By virtue of his position as a teacher, Mr. Law had the privilege of attending several of the Summer training courses in geology and kindred subjects at the Normal College of Science, South Kensington. He had a plain but effective method of teaching, and possessed to a remarkable degree the power of winning the interest and devotion of his students. In a few years he was in rery great demand as a teacher, and had classes every evening in the week, as well as on Saturday afternoons. Among the places at which he taught were Bacup, Rochdale, Shaw, Oldham, Hebden Bridge, Halifax, and Lighteliffe.

His triend Mr. Walter Baldwin, of Rochdale, remarks in a letter that " as a lecturer he had a style peculiar to himself and one which took with the working men, as he never lost his Yorkshire accent, which certainly was a strong one. He and the late $\mathrm{Mr}$. James Horsfall, of Rochdale, were the first to draw attention to the minute flint implements from the Lancashire and Yorkshire Moors." They brought a paper on the subject before the British Association at Montreal. The same authors read before the Manchester meeting of the Association in 1887, a paper "On the discovery of Carboniferous Fossils in a Conglomerate at Moughton Fell, near Settle, Yorkshire" (see Geol. Mag., 1888, p. 30), 